\title{
Gemcitabine Hydrochloride
}

National Cancer Institute

\section{Source}

National Cancer Institute. Gemcitabine Hydrochloride. NCI Thesaurus. Code C961.

The hydrochloride salt of an analogue of the antimetabolite nucleoside deoxycytidine with antineoplastic activity. Gemcitabine is converted intracellularly to the active metabolites difluorodeoxycytidine di- and triphosphate (dFdCDP, dFdCTP). dFdCDP inhibits ribonucleotide reductase, thereby decreasing the deoxynucleotide pool available for DNA synthesis; dFdCTP is incorporated into DNA, resulting in DNA strand termination and apoptosis. 